\title{
対人コミュニケーションに関する実験的研究の動向と課題
}

\author{
小川 一 美 \\ (愛知淑徳大学)
}

Trends and Issues in Experimental Studies on Interpersonal Communication

Kazumi Ogawa

(Aichi Shukutoku University)

\begin{abstract}
This article reviews recent experimental studies conducted in Japan on interpersonal communication. Then, the necessity for studies with a multichannel approach, including the integration of verbal and nonverbal communication is discussed. Next, studies on triadic communication and interpersonal communication from the standpoint of the observer are introduced. Furthermore, issues related to the relationship between studies on interpersonal communication and the construct of social skills, which has recently become a popular study topic, are examined. Finally, four issues are suggested : the explanation of the inner processes of the participants, the necessity for considering the participants' cultural backgrounds, the interest in the study of other fields, and the need to investigate the relationship between interpersonal communication and well-being.

Key Words : interpersonal communication, verbal communication, nonverbal communication, multichannel approach, social skill

本稿では, 対人コミュニケーションに関する最近の日本の実験的研究を中心に概観し, 取り組むべき課題 について言及した。言語的コミュニケーションおよび非言語的コミュニケーションに関する研究をいくつか 挙げ，言語的コミュニケーションと非言語的コミュニケーションの融合も含めたマルチ・チャネル・アプロー チによる研究の必要性についても研究例を挙げながら論じた。続いて，3者間コミュニケーションや観察者 という立場から捉えた対人コミュニケーション研究など，2 者間コミュニケーション以外の対人コミュニ ケーションの捉え方についても紹介した。また，対人コミュニケーション研究にも社会的スキルという概念 が近年多く組み込まれるようになってきたが，構成概念も含めこの両者の関係性については十分な吟味が必 要ではないかという問題提起を行った。最後に，対人コミュニケーション研究の今後の課題として，会話者 の内的プロセスの解明, 文化的背景の考慮, 他分野の研究への関心, well-being との関係を検討する必要 性などについて指摘した。

キーワード：対人コミュニケーション，言語的コミュニケーション，非言語的コミュニケーション，マル チ・チャネル・アプローチ，社会的スキル
\end{abstract}

近年，コミュニケーションカやコミュニケーション能 力といった言葉が研究以外の場でも使われるようになり, 一般の人たちのコミュニケーションに対する関心も高 まっているように感じる。こうした動きに関連して今さ らながら注目をされてきたのが，個人間で行われるコ ミュニケーション，つまり対人コミュニケーションであ る。本稿では, 対人コミュニケーションに関する最近の
日本の研究を中心に概観し，取り組むべき課題について 言及する。対人コミュニケーションは, 記号化と解読と いう行動が中心となっている。しかし, 調查的研究では これらの行動の実態を把握することは難しいため, 筆者 は常に, 実際の「行動」を扱う研究を行うことを心がけ ている。そこで，本稿でも「行動」を独立変数もしくは 従属変数として扱っている研究を中心に取り上げていく 
ことにする。

対人コミュニケーションは, 送り手, メッセージ, チャネル, 受け手, 効果という要素で構成されているが (小川, 2010a)，まずはメッセージに着目し，言語的コ ミュニケーションと非言語的コミュニケーションに関す る研究の動向や課題を探っていく。

\section{I 。ことばと対人関係}

言語に焦点を当てた対人コミュニケーション研究には, 敬語使用に関する研究, 呼称に関する研究, アイロニー に関する研究, 欺瞞のコミュニケーション研究, 説得コ ミュニケーション研究などが存在する。岡本 (2010) は, 語用論, 社会言語学, 心理言語学の研究成果を念頭に置 いたうえで，ことばに対する社会心理学的な立場からの アプローチが行われた研究をまとめている。そこでは, 社会心理学的なアプローチの特徴として, ことばが対人 過程の中でどのように発話され理解されるか, ことばが 対人関係とどのように関わり合うかという点が強調され ている。まずは本稿でも, 言語に焦点を当てた最近の心 理学的研究を挙げてみる。

ある言語を独立した言語と認めた場合, 方言はその中 でのバリエーションを指す（岡本，2010）。日本の方言研 究は方言の地理的な分布を調査し, 方言区画を行う言語 地理学に代表されるように, 方言の収集・記録に重点が 置かれていた。しかし，海外では，方言（アクセント）を 用いる話し手に対する評価に関する実験的研究が多く行 われており (Giles, 1971 など), 日本でも方言と共通語の 話し手の印象比較などが行われるようになった（岡本， 2001 など)。町・樋口・深田 (2006) は, 方言の使用が適切 な場面とそうでない場面を設定し, 方言と共通語, さら には場面に応じたことばの使い分け (コードスイッチ) の 効果を実験によって明らかにしている。コード・スイッ チングは, 会話者間の理解を高めるために行われること があるが，社会的アイデンティティとの関連から生じる こともある。また, Giles, Coupland, \& Coupland (1991）によるコミュニケーション調節理論（communication accommodation theory) における相手の発話スタイル への収束や分離として捉えることも可能である(岡本, 2010)。このように言語やことばの使用も対人関係に対 する影響力を持っているが，なぜそのような使用になる のかを心理学で用いられる理論に基づき解釈することで, 言語と対人関係の関連をより深く理解できるようになる。 ただし，そうした研究はまだ十分に行われていないのが 現状である。

欺鿃のコミュニケーションに関する研究として, 言語 的コミュニケーションの特徵に着目したものもある。
Grice（1975）によると，会話には必要な量の情報を述べ るという量の公準，偽りであると信じていることは言わ ないという質の公準，関係のあることを述べるという関 係の公準，曖昧な表現を避けるという様式の公準という 4 つの会話の公準がある。この会話の公準が違反された 場合に, 人は欺瞞性を感じるという情報操作理論がある (McCornack, 1992)。村井 (1998, 2004) は，情報操作理論に 基づき, 会話の公準に違反した発言内容を文章で呈示し, 受け手による欺瞞性認知を測定するという実験を行った。 また，強調語が発言内容の欺瞞性認知に及ぼす影響に関 する研究にも取り組んでいる(村井, 2005)。欺瞞ではない が真実を表明しない発話として，アイロニーに関する心 理学的研究も行われている(石田・阿部, 2010 など)。ただ し, アイロニーの実験的研究については, 岡本 (2004) に詳しく記されているので，そちらを参照されたい。良 好な対人関係とは, 常に真実のみを表明し合う関係であ るというわけではない。うそやアイロニーは社会的文脈 によって多様な効果をもたらすものであり, 欺瞞のコ ミュニケーション研究などはこうした言語と対人関係が 相互に強く影響し合う様を示す 1 つの典型として注目し ていくべきではないだろうか。そこから得られる知見は, 限定的な目的的コミュニケーション場面という枠を超え て，より広く活用可能であると思われる。

言語使用や限定的場面に扔けるコミュニケーションで はなく，より広い日常会話におけることばに注目してい る研究もある。調查研究ではあるが多川・小川・斎藤 （2006）は，内面性の低い次元に含まれるような些細な内 容の日常会話が対人関係の中で果たす役割も大きく，そ れらについて検討する必要があるとして，まずは話題と なりうるテーマの重要度比較を行っている。Duck, Rutt, Hurst, \& Strejc（1991）は，これまで見過ごされが ちであった日々の出来事や状況に目を向け，日常的に習 慣となっているようなコミュニケーションを検討すべき だと指摘している。多川・吉田 (2006) では，日常の些細 なコミュニケーションが恋愛関係の良好さに影響を及ぼ すことが示された。内面性の高い自己開示が精神的健康 や対人関係の親密化にとって重要であることに異論はな いが，「うわさ話」や「雑談」などの日常の何気ない会 話は全会話のおよそ半数を占めていることからも（Goldsmith \& Baxter, 1996)，些細なやり取りだと軽視すること なく，その機能などについて検討していくことも重要で あろう。な扔，対人コミュニケーションという観点から 「うわさ」に着目をした研究も行われている（竹中, 2005, 2007)。さらに，日常会話で頻繁に出現する “ある個人 が他者におかしさを感じさせることを意図して表出する 言葉”である「攵談」に注目し，対人関係との関連を検 
討した研究もある (葉山・櫻井, 2008a, 2008b)。咒談と類似 する概念として「ユーモア」というものがあるが，これ に関してもなぜ人はユーモア表出を行うのかという調査 的研究などがある (塚脇·越・樋口・深田, 2009)。これらの研 究も, 日頃の何気ない会話の中で繰り広げられることば のやりとりに焦点を当て，一見些細に思えるものでもそ の積み重ねは対人関係を左右する力を持っていることを 結果として示している。

\section{II．非言語的コミュニケーションに関する研究}

これまで, 視線の機能, 表情表出, 表情解読の特徵な どに関する実験的研究が行われ，対人コミュニケーショ ンにおいて視線や表情が果たす役割の大きさが主張され てきた。遠藤（2008）も，“視線は特にその送り手の意図 がどこに注がれているのかを，そして表情は特にその送 り手の心的状態がいかなるものであるのかを，時に言葉 以上に精妙に私たちに指し示してくれるという意味にお いて，きわめて高度な情報価を有している”と述へてい る。しかし, その一方で視線や表情がいかなるメカニズ ムでどのような社会的情報のやりとりを可能ならしめて いるかについては未だ明確にされていないという指摘も している。表情に関して言えば, “そもそも表情は情動 を映す鏡なのか”という問いと，“もし表情がいかなる 形であれ情動と関連性を有するものであるとすれば，表 情は情動に関する情報をどれだけ，また，どのように発 するのか”という問いが存在し，この 2 つの問いは，表 情がどのような意味をいかなるメカニズムで発している かという未解決な問題に対する主要な論点となっている (遠藤, 2000, 2008)。対人コミュニケーション研究として, 人はどのような文脈下でどのような記号化を行うのか， どのようなメッセージ (ノンバーバルも含む)に対してど のような解読を行うのか, その精度はいかなるものかと いった研究は行われてきた。しかし, 遠藤 $(2000,2008)$ が指摘する問いに対する解となるような研究は十分でな く,これらの問いに対する理論的かつ実証的な研究が蓄 積されていけば, 表情に関する記号化や解読行動のより 詳細なメカニズムを説得力ある理論と共に解明すること が可能になるのではないだろうか。上出・大坊（2007）な どは，文化的背景も考慮した上で社会的スキルと表情の 関連を検討しており，顔面部位による差はあるものの総 じて社会的スキルが高い人は表情が豊かであることを明 らかにしている。こうした社会的スキルの高さと記号化 や解読力の関連も, 遠藤 $(2000,2008)$ が指摘した問いと 無関係ではない。たとえば，社会的スキルの高い人とそ うでない人では, 表情と情動の関連に関する知識や信念 が異なっている可能性があったり，情動に関する情報が
表情として発せられる量や形態に違いが生じたりするの であれば, 表情と情動の関連は個人差という変数を媒介 させることで整理できる側面があるのかもしれない。

個人特性を組み込んだ非言語的コミュニケーション研 究として, 落合・松井 (2009) は, 対人不安特性の高さに 着目し，他者表情の認知に関する実験的研究を行った。 対人不安とは “現実の，あるいは想像上の対人場面にお いて，他者からの評価に直面したり，もしくはそれを予 測したりすることから生じる不安状態” (Schlenker \& Leary, 1982, p.642) である。Clark \& Wells（1995）は，対 人不安の高い者には対人場面において否定的な解釈をし やすいという認知傾向があり，そのことは実際の対人関 係にも悪影響を与えることがあるという指摘をしている。 落合・松井（2009）はこの指摘に基づき，コミュニケー ション相手の表情が変化する対人場面において, 対人不 安特性の高さが表情認知に与える影響を検討した。その 結果, 対人不安の低い者は, 否定表情を示された際に認 知した相手の否定感情が強いほど，その後肯定表情を示 されると肯定的な感情を強く抱いていた。しかし，対人 不安の高い者は，否定表情を示された際に認知した相手 の否定感情が強いほど，その後肯定表情を示された際に は否定的な感情が促進されていた。つまり, 対人不安の 高い者は, 相手の感情の肯定的な変化を受け入れにくい 傾向を持つと考えられる。この結果について落合・松井 （2009）は，“高対人不安者は相手の表出感情が否定から 肯定へと変化する場面において，その相手に対して不適 切に反応してしまうことが示唆された。さらに，高対人 不安者は, この不適切な反応により, コミュニケーショ ン相手が一時的に否定感情を表出しただけでその関係を 壊してしまったり，あまり関係が良好ではなかった相手 との関係改善のチャンスを逃してしまったりすると予想 される”としている。Leary（1983 生和監訳 1990, p. 194）は，“対人不安は，その結果として，対人関係の効 果を低め，その他の楽しい会合での喜びを減らしたり， 人久の社会生活上に好ましくない効果をもたらす行動 的・認知的な反応を伴っている。行動科学のさまざまな 領域の見解と成果を統合することによって, 心理学者は, 対人不安をよりよく理解し，より効果的に対処できるよ うになると期待したい”と研究に対する提言を行ってい る。Leary の提言からは長い年月が経っているものの, 対人不安の高い者の不安が解消されているわけではない。 落合・松井 (2009) のように，対人コミュニケーション研 究としてょり詳細に対人不安傾向の高い者の解読や記号 化の特徵やメカニズムを解明していくことは, 高対人不 安者に対する効果的な治療の開発という点でも貢献でき るのではないだろうか。 
ここまで非言語的コミュニケーションの視覚的チャネ ルに関する研究を挙げてきたが, 非言語的コミュニケー ションには音声的チャネルであるパラ言語も含まれてい る。話者の性格印象に影響を与える要因として, 発話速 度 (内田, 2002), 声の高さと発話速度 (内田・中畧, 2004), 発話速度と休止時間 (内田, 2005a), 音声中の抑揚の大き さ(内田, 2005b) などに着目した研究があり, これらは日 本人の音響的特徵の基礎的な情報として非常に貴重であ る。

\section{III.マルチ・チャネル・アプローチによる研究}

メッセージには，言語的コミュニケーションと非言語 的コミュニケーションが含まれる。非言語的コミュニ ケーションには, さらにパラ言語, 視線やジェスチャー や顔面表情といった身体動作，被服や化粧といった人工 物など複数のものが含まれる。実際のコミュニケーショ ンでは, これら複数のものが同時にメッセージとして送 受信されているにもかかわらず，研究としてはいずれか 1 つの要素 (単一チャネル) に着目して検討されることが 多い。しかし, 単一チャネルによる研究が蓄積されたと しても，必ずしもそれらの知見が加算的に人間のコミュ ニケーションの実態を把握することにつながるわけでは ない。

視線量と発話速度が説得性や信頼性認知などに及ぼす 効果を検討した研究では (Yokoyama \& Daibo, 2008), 発 話速度が遅く, 視線量が少ないときに信頼性は最も低く なるなどといった交互作用効果が示されている。また， 荒川・鈴木 (2006) は，発話のパラ言語的特徵と手のジェ スチャー頻度が共変化する対人的条件が存在することな どを見出している。これらは, 単一チャネルによる研究 では明らかにされない結果である。また，欺瞞のコミュ ニケーション研究では, 統制可能性の高さの違いから, 真意が漏洩しやすい部位や行動特徵が存在したり, 複数 のチャネル間で表出パターンに不一致が生じたりするこ とがある (deTurck \& Miller, 1985 ; Knapp, Hart, \& Dennis, 1974 ; O’Hair, Cody, \& McLaughlin, 1981 など)。一方の受け手 についても, 日常では視線のみ, ジェスチャーのみと いった単一のチャネルに着目しているわけではなく, 複 数の記号を手がかりに解読を行っている。そして, 複数 チャネル間で表出パターンが一致していないことに気づ き，疑念を抱くということもあるだろう。こうしたこと からも, 非言語的コミュニケーションのマルチ・チャネ ル・アプローチは重要であるとされている（守㠃, 2010 ; 横 山, 2010 など)。

さらに, マルチ・チャネル・アプローチは, 非言語的 コミュニケーションに限ったものではなく, 言語的コ
ミュニケーションと非言語的コミュニケーションのマル チ・チャネル・アプローチを試みた研究もある。

小川（2008）は，初対面の 2 人の会話が相互作用を重 ねることでどのように変化していくのかを，発話量に着 目し検討した。発話の機能に注目したStiles（1992など） の Verbal Response Modes (VRM) というカテゴリー に全発話を分類し，それぞれの出現時間と頻度を計測し ている。この研究における発話量とは，「何を」「どれく らい」話すのかという意味で, 言語と非言語のマルチ・ チャネルである。様々な分析から，どのような機能の発 話を行うのかという言語的側面と，どれくらいの量を発 するのか，相手よりも多いのか，同じくらいなのかとい う非言語的側面の相互の組み合わせによって，相手に与 える印象は異なることが示された。また，小川 (2006) は，同一の会話を文字という言語情報だけで呈示するテ キスト条件，文字を実際の発話の夕イミングに合わせて モニター上に呈示するテキスト十交替潜時条件, 音声と して呈示する音声条件, 会話時の会話者映像も呈示する ビデオ条件という 4 条件を設け，こうした手がかり情報 の違いが会話者や会話に対する印象に与える影響の違い を分析した。この研究では，単に言語的側面，非言語的 側面という区別だけではなく，非言語的側面を視覚的 チャネル（表情, ジェスチャーなど）と音声的チャネル（パラ 言語）に分けたことで，初対面の会話場面という限られ た場面ではあるが，音声情報に視覚情報が加わっても印 象に大きな差は見られないということなども示されてい る。

ところで，メッセージを送受信する際，言語的コミュ ニケーションに含まれる意味と, 非言語的コミュニケー ションに含まれる意味が必ずしも一致するとは限らない。 言語的には肯定的な意味なのに，表情などの非言語チャ ネルが否定的な意味を表しているということはよくある ことである。佐々木 (2006) は, 言語メッセージと非言 語メッセージに含まれる意図が一致しない条件の場合, 言語メッセージと非言語メッセージのいずれのメッセー ジが，受け手による意図帰属や感情反応，さらには言語 行動に強い影響を与えるのかに注目した。言語メッセー ジと非言語メッセージが不一致であるとき，より信頼で きる情報源として非言語メッセージが用いられるという， 言語一非言語一致性原則（Blanck \& Rosenthal, 1982）と, メッセージの言語の解釈に注意が向けられることによっ て非言語メッセージの解釈に相対的に注意が向けられに くくなり, 非言語メッセージが意図㷌属に与える影響が 小さくなるという, 連合処理モデル（佐々木, 2005）のい ずれが適用されるのかを実験的に検討した。その結果， 好意的な言語メッセージを敵意的な非言語メッセージを 
伴って伝達した場合は，敵意的な言語メッセージを好意 的な非言語メッセージを伴って伝達した場合よりも，好 意が強く敵意は弱く㷌属され, 怒り感情も弱くなってい た。つまり，非言語メッセージよりも言語メッセージの 方が優勢であるという連合処理モデルに則した結果で あった。その一方で，送信者の依頼を受け入れるかとい う受容行動に関しては, 敵意的な非言語メッセージを伴 う好意的な言語メッセージの方が，好意的な非言語メッ セージを伴う敵意的な言語メッセージょりも，依頼を受 け入れにくいことが示された。すなわち, 受容行動に対 しては非言語メッセージの効果が優勢となり, 言語一非 言語一致性原則に則した結果となった。結論として佐久 木 (2006) は，心理反応によって言語メッセージと非言 語メッセージのいずれに注意が向けられるかが異なるが, この結果を一般化するためには，さらに多様な社会的状 況や測定尺度を用いて検討する必要があるとしている。

欺瞞のコミュニケーション研究に関しても, 村井 （2005）は，発言内容にパラ言語的要素が加わることで, 異なる効果が生じる可能性が考えられることから, 言語 的コミュニケーションと非言語的コミュニケーションの マルチ・チャネル・アプローチの必要性が課題であると している。そして, 一方のみを検討することが無意味で あるわけでは決してなく, 言語のみを検討し, その後, 音声について検討していくというょうに，順次対象を拡 張していくことが妥当であると述べている。

Patterson（1983 工藤監訳 1995）が指摘したように，現 実場面での要素間の相互依存関係を検討するためには, 複数の要素の組み合わせによる多変量アプローチが優れ ているが，1つ1つの要素に関する知見の体制化も必要 である。マルチ・チャネル・アプローチと単一チャネル・ アプローチによる研究が相互に補完し合い融合されてい くことで，リアリティのある対人コミュニケーションの 把握が可能となる。また, 実験的研究ではできる限り剩 余変数を削除，統制することができる点が長所であるが， 時にこの追求が不自然かつ非現実的な状況設定につなが ることがある。特に, 対人コミュニケーション研究では, 剩余変数の扱いをはじめとした厳密な条件統制とリアリ ティの追求のバランス維持が求められる。

\section{IV。3 者および観察者に着目する研究}

\section{3 者間コミュニケーション}

磯・木村・桜木 ・大坊 $(2003,2004)$ は, 日常生活に扔い て相互作用の相手は 1 人とは限らず, 集団内で協調して 何らかの成果を求められる場面も多いことから，3 者間 の会話場面に着目する必要性を指摘し, 非言語的行動が もたらす効果を検討した。 3 者間では直接的に形成され
る印象の他にもう 1 人の会話者を介したメ夕認知も関連 することから，配慮行動やコミュニケーション配分が重 視されるとしている。実際に 3 者で会話をさせるという 実験を行っているが，討論条件において視線量が多い場 合に好意的な印象を獲得する傾向が見られ，均等な視線 配分が感じの良いという印象につながることなどが見出 された（磯他, 2004)。また，うなずきに関しては討論条件 で会話満足度や好印象との関連が示され，一方，笑顔は 親密条件では好印象をもたらすにもかかわらず，討論条 件では会話満足度を低めることなどが示された（磯他, 2003)。さらに，木村・磯・桜木・大坊（2005）は，2 者を 対象にした先行研究の知見を 3 者間コミュニケーション に単純に適用することはできないにもかかわらず，これ まで 3 者間コミュニケーションに注目した研究がほとん ぞなされていないことは問題であるとした。そして，3 者間会話場面と 2 者間会話場面の共通点と相違点を整理 し，笑顔とうなずきという視覚的情報を有するコミュニ ケーション行動に着目した実験的研究を行った。その結 果, 笑顔に関しては討論条件でも親密条件でも本人の会 話満足度と関連は見られなかったのに対し，うなずきに ついては討論条件でのみ本人の会話満足度と有意な正の 相関関係が見られた。さらに，同調傾向の一種である 「行動マッチング」が 3 者間コミュニケーションにおい ても生じることが確認され，討論条件ではうなずきマッ チングと会話満足度との有意な関連が示された。つまり, 3 人同時にうなずきが生起するということは，場に提出 された意見に対し 3 人のコンセンサスが形成されたこと を意味するため会話満足度が高まったと考えられる。

以上の他にも，藤本・大坊 $(2007 \mathrm{a}, 2007 \mathrm{~b})$ など 3 者間コ ミュニケーションを取り上げた研究も行われるように なってきた。 3 者以上のコミュニケーション研究がなぜ 必要なのかについて，大坊（2006a）では次のように述心゙ られている。“2 者間に比べて 3 者以上の相互作用では 共有される場の境界が曖昧になり，積極的な介入を示さ なければ会話の場の枠から排除されてしまう可能性があ るので， 2 者とそれ以上の集団とではコミュニケーショ ン行動に大きな違いがある” (大坊, 2006a)。2 者より 3 者, 3 者よりそれ以上というように数が増えれば当然, 扱う 現象も複雑になっていく。しかし，それに臆することな く挑んでいかなければ，現象の本来の姿を捉え損ねてし まうことになる。

\section{2. 観察者という立場からの対人コミュニケーション}

会話者として関与するわけではないが，2 者の会話を 第三者的に観察する人物に着目する研究もある。これま で対人コミュニケーションに関する研究では，情報交換 の効率性, 対人関係の構築や維持という観点から, 対人 
コミュニケーションの当事者である会話者に焦点が当て られてきた。しかし，木村・大坊・余語（2010）は，人は 観察者として他者の対人コミュニケーションを認知し, その情報をもとに周囲の人間関係を理解しており，自ら が対人関係を円滑に展開し集団生活を快適に営むために は, 観察者の立場から他者の対人コミュニケーションを 認知する際の判断精度が重要になると指摘している。

Bernieri, Gillis, Davis, \& Grahe（1996）は，話者の表 出行動が活発であれば，そのコミュニケーションはうま くいっていると観察者が判断してしまう表出性ハロー (expressivity halo) 効果という現象を見出した。木村・余 語・大坊（2005）は，高コンテクスト文化である日本でも この現象は生じるのか, 話題の感情価によって表出性八 ロー効果が対人コミュニケーションの認知に与える影響 は異なるのかなどについて実験を行った。その結果，日 本人大学生を対象にしても表出性ハロー効果が生じるこ と，また，ネガティブ感情エピソードではポジティブ感 情エピソードよりも観察者による対人コミュニケーショ ンの認知が不正確になることが確認された。さらに，木 村他（2010）は，観察者の対人コミュニケーション認知 を社会的スキルの 1 つに位置づけることの妥当性の検討， および判断精度向上に必要な基礎的知見の獲得を目的と した実験的研究を行った。その結果, (1)対面交渉能力の 違いにかかわらず, 表出性の高い会話より表出性の低い 会話の方が, 観察者による対人コミュニケーション認知 の判断精度が低下すること, (2)表出性の高い会話では, 対面交渉能力の高い者は低い者に比べて, 観察者による 対人コミュニケーション認知の判断精度が高かったのに 対し, 表出性の低い会話では, 対面交渉能力の違いが見 られなかったこと, (3)観察を重ねただけでも, 観察者の 立場での対人コミュニケーション認知の判断精度が向上 することなどが明らかとなった。木村他（2010）の研究 は, 観察者という立場に焦点を当てることの積極的な意 義を主張している点, 対人コミュニケーション認知とい う基礎的な実験的研究を社会的スキル・トレーニングに まで発展させようとしている点など, 注目すべき点が多 くある。

小川 (2003a, 2003b) は, 発話量の均衡が会話者や会話 に対する印象に及ぼす影響について，会話者という立場 と観察者という立場それぞれから検討した。その結果, 会話者の場合は応答量や質問量が均衡していると相手に 対して親しみやすさを感じるが, 観察者の場合は発話量 の均衡状態と会話者に対する印象には特徴的な関連は見 られないというように, 立場の違いにより異なる結果が 示される部分があった。一方で, 会話者であっても観察 者であっても相づちなどの応答量が 2 者間で同程度の場
合に心地よい会話であったと判断するというように，立 場が異なっていても同様の特徵を示す点もあることが明 らかとなった。

観察者は，会話者とその 2 人によって作り上げられる 会話を客観的に観察するため会話事態の多様な側面に注 目することができる。それに対して会話者は，自らが相 互作用を行っており自身を客体視することは容易でない ため，相手の会話者に関する要因に注目をすることが多 くなることが考えられる。さらに，会話者は観察者より も会話への関与度が強く, 相手との関係性についても強 く意識するため，相手の話した内容についてよく記憶す ることができるかもしれない。したがって，対人コミュ ニケーションに関する研究では, 誰による認知なのか, 誰に詨する効果なのかという対象の違いについて敏感に なる必要がある。木村他（2010）が指摘するように，円 滑な対人関係を展開して，集団生活を快適に営むために も，観察者の立場から他者の対人コミュニケーションを 認知するという行為は重要であるため, 観察者の立場と しての対人コミュニケーション研究を積み重ねていくこ とが求められる。

\section{$\mathrm{V}$ ．社会的スキルと対人コミュニケーション}

木村・磯・大坊（2004）による二者間会話に関する実験 的研究では, 社会的スキルの高い者は低い者に比べて視 線量が多く，自己接触が少ないことが明らかにされた。 これは，社会的スキルの高い者は，相手に多く視線を向 けて情報収集を行っており，自己接触を控えることで相 手に神経質な印象を与えないように印象管理を行ってい たためと解釈されている。また，谷村・渡辺（2008）によ る大学生の初対面場面での二者間会話に関する実験的研 究からは, ソーシャルスキルが高い者の方が低い者より 相手に質問をする頻度が多いことなどが示されている。 そして, “大学生が初対面でコミュニケーションをス ムーズに行うためには，ソーシャルスキルを高めること が必要なことが明らかとなった”と述べられている。

社会的スキルと対人コミュニケーション行動の関連を 検討する研究は増えているように思うが，社会的スキル を高めることと良好な対人コミュニケーションを行うこ ととは，決して別物ではないはずである。社会的スキル の定義は多様であるが，たとえば相川（2009）は，“ソ一 シャルスキルとは，対人場面において，個人が相手の反 応を解読し, それに応じて対人目標と対人反応を決定し, 感情を統制したうえで詨人反応を実行するまでの循環的 な過程”としている。つまり，社会的スキルが高いとい うことは，良好な対人コミュニケーションができるとい うことである（ただし, 社会的スキルには広範な対人行動が含ま 
れるため, 良好な対人コミュニケーションができること以外にも 様々な行動が含まれる)。社会的スキルを測定する尺度の項 目に，対人コミュニケーションに関わる行動ができるか どうかといった項目が多数含まれていることからもわか るように, 社会的スキルという概念を目に見える行動と いう形で表しているのが，対人コミュニケーションなの ではないだろうか（くどいようだが, 社会的スキルには対人コ ミュニケーション以外の広範な対人行動も含まれる)。対人コ ミュニケーション研究に限らず, 社会的スキルという概 念が非常に多くの研究で個人特性の 1 つとして使用され ている。そして, 多くの研究で社会的スキルの高さに よって対人行動に違いが生じることが示されている。し かし, それらの研究の中には, 社会的スキルが原因と なって当該の対人行動が影響を受けたことを証明したの ではなく，尺度で測定した社会的スキルの高さを対人行 動という異なる側面で証明したという, ある種, 尺度の 妥当性検討の研究になってしまっているものもあるので はないだろうか。この点に関しては, 対人コミュニケー ション研究においては特に留意が必要である。決して, 尺度で社会的スキルが高いとされた人がどのような対人 行動を示すのかを検討するような研究に意義がないと 言っているわけではない。しかし, 最近の対人行動に関 する研究を概観すると, 社会的スキルを説明変数として 扱っている研究が非常に多い。社会的スキルという概念 を何でも説明してしまう便利な概念として扱うことのな いように研究者は留意すべきであろう。

\section{VI. 今後の課題}

ここまでにも引き続き検討されることが望まれる対人 コミュニケーション研究のアプローチや視点を挙げてき たが, その他にも今後の課題として考えられる観点があ る。それらを以下に整理してみる。

\section{1. 会話者の内的プロセスの解明}

良好な対人コミュニケーションのためには，伝えたい ことを適切な方法で効果的に受け手に伝える記号化と, 送り手によって記号化されたメッセージを受け取り，そ のメッセージの意味を適切に解釈する符号解読が重要で あることは改めて言うまでもないだろう。しかし，伝え たいことを正確に伝え, 送られたメッセージを正確に解 読することは決して容易なことではない。他者からは知 覚できない自己の内的経験が他者に知られていると過大 推定する傾向のことを，透明性の錯覚（illusion of transparency) と呼ぶが (Gilovich, Savitsky, \& Medvec, 1998), 武 田・沼崎 $(2007,2009)$ は，ミスコミュニケーションの原因 となりうる判断のバイアスの 1 つとして, 透明性の錯覚 に着目し実験的な研究を行っている。メッセージの送り
手が，受け手に自分の内的経験が伝わっていると思う程 度を実際以上に過大評価する傾向を“行為者の透明性の 錯覚”とし，メッセージの受け手が送り手の内面を見抜 いていると思う程度を実際以上に過大評価する傾向を “観察者の透明性の錯覚”とし，2 種類の透明性の錯覚 を分けて検討している。その結果，送り手と受け手の双 方に透明性の錯覚が生じており,さらに，相手との関係 が親密である場合の方がそうでない場合よりも透明性の 錯覚が大きいことが示された。太幡（2010）は，透明性 の錯覚の程度に被透視感が影響を与える可能性があると 考察している。被透視感とは, 相互作用する相手に直接 的に伝えていないのに，自己の内面を気づかれているか もしれないと感じる感覚であり（太幡, 2006), 気づかれた くない事柄への被透視感である懸念的被透視感（太幡, 2008）と，気づいてほしい事柄への被透視感である期待 的被透視感（太幡・吉田, 2008）がある。相手への意図の伝 達の程度に期待的被透視感を感じて曖昧な表現を用いて しまうことで，実際には伝わっていないのに伝わってい ると錯覚してしまう透明性の錯覚が生じる可能性などが 挙げられているが (太幡, 2010), 親密な関係の方が透明性 の錯覚が大きくなるのは，こうしたわかってくれるはず という期待とも甘えとも捉えられる思いが関連している と考えられる。

なお，内的プロセスに関しては，発言をしないという 発言抑制行動の原因や動機の解明を行った研究（畑中, 2003）や，発言抑制行動前に生起する意識内容を手がか りとして，発言するか否かを決定する際の内的過程を検 討した研究（畑中, 2006）などもある。

これらの研究は, 単にどういう状況や場面, 行動の場 合にミスコミュニケーションが生じやすいのかや発言を 抑制してしまうのかではなく，なぜミスコミュニケー ションが生じてしまうのか, なぜ発言をしないのかを会 話者の内的プロセスまで踏み込んで検討している。「な ぜ」を追究することは心理学研究の究極の目的であろう。 日本に打ける対人コミュニケーション研究は,この点が 弱かったように思われる。自戒の念も込め今後の課題と して挙げておく。

\section{2. 文化的背景の考慮}

顔面表情に関して文化比較を行った研究がある（工 藤・マツモト, 1996 ; Matsumoto \& Ekman, 1989 ; 中村, 1991, 1993 など)。これらに基づき大坊（2007）は，文化によって典 型とされる顔面表情は異なり, 顔自体や顔によるコミュ ニケーションが心理的，社会的に有する効果は文化を超 えて同じとは言えず，文化的な背景を考慮した上で，顔 によるコミュニケーションの機能や役割を明確にしてい く必要があると指摘している。文化的な背景を考慮する 
必要があるのは顔面表情に限らず，他の非言語的コミュ ニケーションに関しても同様である。さらに，中村 （2000）は，表情に対する尺度評定を日米比較した Matsumoto \& Ekman (1989) の研究と中村 (1993) の研究を取 り上げ，前者では「感情表出の強さ」を評定させていた のに対し, 後者では「表出者の感情経験」を評定させて いたことから，相反する結果が得られていたことについ て論じている。これは, 文化的な背景の異なるグループ を比較する際には，測定するものさしを一致させること が重要であるが，それには困難さが伴うことを示した例 と言えよう。

言語的コミュニケーションに関しても，岡本 (1985) が，言語的スタイルが関連する説得研究のほとんどが欧 米で行われて扔り, 大部分が英語を母語とする参加者が 対象であるため, それらの研究は追試不能であったり, 追試しても無意味であったり, 追試可能な場合でも全く 異なる結果になったりするだろうと指摘している。日本 語話者と欧米語話者の違いについて, “言語的に隔たり があり，文法上の特徵がかなり異なる”，“社会言語学的 にも差違がある”，“非言語的音声的コミュニケーション の用いられ方にも, 多くの場合差違がある可能性が強 い”，“社会的・文化的生活習慣の差違があるため, 欧米 で説得効果を高めるのに有効だとされる要因が，必ずし も等価な力を持たない”ことなどを挙げている。さらに “日本語による研究は, 日本語の特徵, 日本社会でのコ ミュニケーションの特徵, さらには日本社会の特徵を十 分に見極めた上で, 従来の欧米での諸研究と共通に論じ られる面, 論じられない面を, 明確に把握して発展させ ていかねばなるまい”としている。これは 15 年前の指 摘ではあるが, 今もな扔, 対人コミュニケーション研究 の課題となっている。

\section{3.メディア・コミュニケーション研究や他分野の研究 への積極的関心}

本稿では，主に対面状況でのコミュニケーションに関 する実験的研究に焦点を当てて研究の動向や課題を述べ てきた。対面状況に限定したのは, “対人コミュニケー ションは，対面状況でのコミュニケーションを基本とす る”という深田（1998）の主張に基づいたためである。 しかし，近年のコミュニケーション状況を考えると，メ ディア・コミュニケーションが個人や対人関係に果たす 役割は非常に大きい。古谷・坂田（2006）は，青年期の友 人関係において, 対面, 携帯電話, 携帯メールでのコ ミュニケーションがどのように展開されているのかを探 り，それらが対人関係の維持にどのような役割を果たし ているのかについて調査研究を行っている。その結果, 近距離友人では, 基本的に対面ですべての内容のコミュ
ニケーションを行うことが関係維持につながり，加えて， 携帯メールの課題的コミュニケーションや情緒的コミュ ニケーションも関係維持につながることが示された。一 方の遠距離友人では，対面でコミュニケーションができ ないがゆえに，携帯電話や携帯メールでのコミュニケー ションによって関係の維持を図っている可能性が示唆さ れた。つまり, 近距離友人と遠距離友人では関係維持の メカニズムが異なり，両方の関係を維持するためにはメ ディアの使い方を柔軟に変化させてコミュニケーション を行う必要がある。こうした知見は, 対面状況に限定し た対人コミュニケーション研究からは見出されない。現 代の人々のコミュニケーション状況を捉えるためにも， そして, 対面チャネルの持つ機能の特徵を明確にするた めにも，メディア・コミュニケーション研究の知見が重 要になってくる。

心理学内の他の研究テーマだけでなく,さらに視野を 広げ他の学問分野にも関心を持ち, 学際的な研究を行う ことなども対人コミュニケーション研究の発展には必要 である。岡本 (2010) は, “ことばに関わる諸現象には, 言語間，文化間で異なりがあることが当然予想される” とし，日本語を対象とした研究を主に紹介している。特 に，日本では対人コミュニケーションに関する社会言語 学的研究等は多く行われているため, それらについて社 会心理学的観点から興味深いと考元られる研究を多く引 用している。対人コミュニケーションに関しては心理学 以外の分野での研究は多く蓄積されてきている。岡本は 以前からこうした他分野の研究に着目し，それらと心理 学的研究を結びつけてきた。心理学以外の学問分野の研 究知見と心理学的研究の知見の共通点や相違点を整理し たり, 他の学問分野の研究を心理学的に考察し直したり することで, 心理学的研究の特徵 (欠点も含む) が見えて くるだろう。

\section{4. 対人コミュニケーションと well-being}

大坊 (2006a) によると，適応的な生き方をするために は，社会的スキルを磨き対人関係を円滑にすることが必 要であり, その中心となる問題は対人コミュニケーショ ンであるとされている。つまり，良好な対人コミュニ ケーションは適応的な生き方, well-being につながっ ていく。well-being を追究するために必要となる研究 の中にも，コミュニケーション力に関する研究が挙げら れている(大坊, 2009)。ただし，コミュニケーション力と いう概念そのものが明確でないという大きな問題がある が，これについては小川（2010b）などを参照されたい。 さらに，大坊 (2006b) は，“幸福や健康を目指したコ ミュニケーションの効用を十分に理解した上で，相互協 調的な高質な社会を築く努力が求められる”と指摘して 
いる。2010 年の日本心理学会第 74 回大会では,「wellbeing を高めるためのコミュニケーション力一社会的ス キルの研究一」というシンポジウムが開催された（詳細 は「対人社会心理学研究第 11 号」に揭載予定)。対人コミュニ ケーションが個人の求める well-being と社会としての well-being の双方にどのように関連していくのか，さ らには両 well-being を高めるための対人コミュニケー ションとはどのようなものかを追究していく研究が求め られている。

\section{VII. おわりに}

対人関係と対人コミュニケーションは循環的な関係に あり，相互に影響を与え合い，常にダイナミックに展開 をしている。対人関係と一言で言っても, 関係の種類, 関係の進展段階など多様な要因が絡み合っており，一方 の対人コミュニケーションも構造や要素, 様態など非常 に多様な捉え方が可能である。人が日々の生活の中でコ ミュニケーションという行為に費やしている時間や，そ こから受ける影響力を考えたとき，それに相応する程の 心理学的な対人コミュニケーション研究が十分なされて いるとは言えない。その原因の 1 つは，対人関係と対人 コミュニケーションのダイナミックスさや複雑さなのか もしれないが，そこに挑む研究が増えていくことを期待 している。そして，本稿を執筆することで，視点を変え れば対人コミュニケーション研究として捉えることがで きる研究は意外に数多くあるのかもしれないということ に気づくことができた。しかし，十分な整理と統合が未 だできていないため，残念ながらその気づきをうまく本 稿に反映させることはできなかった。対人コミュニケー ション研究として行われたわけではない研究の知見も, 多角的に対人コミュニケーションを捉えうるものになる ことがある。それらを見出すためにも，今まで以上に柔 軟な視点で心理学の動向を追っていきたいと思う。

\section{引用文 献}

相川 充 (2009). 新版 人づきあいの技術一ソーシャ ルスキルの心理学一 サイエンス社

荒川 歩・鈴木直人 (2006). ジェスチャーは会話ス夕 イルの一部か? 一発話の近言語的特徴とジェスチャー 頻度との関係およびその性差一 対人社会心理学研 究, 6, 57-64.

Bernieri, F. J., Gillis, J. S., Davis, J. M., \& Grahe, J. E. (1996). Dyad rapport and the accuracy of its judgment across situations : A lens model analysis. Journal of Personality and Social Psychology, 71, 110-129.
Blanck, P. D., \& Rosenthal, R. (1982). Developing strategies for decoding "leaky" messages : On learning how and when to decode discrepant and consistent social communications. In R. S. Feldman (Ed.), Development of nonverbal behavior in children (pp. 203-229). New York : Springer-Verlag.

Clark, D. M., \& Wells, A. (1995). A cognitive model of social phobia. In R. G. Heimberg, M. R. Liebowitz, D. A. Hope, \& F. R. Schneier (Eds.), Social phobia : Diagnosis, assessment, and treatment (pp. 69 -93). New York : Guilford Press.

大坊郁夫 (2006a). 社会的場面を考慮したコミュニ ケーション・スキルの研究 電子情報通信学会技術研 究報告, HCS2005-55 (2006-01), 1-6.

大坊郁夫 (2006b). コミュニケーションが築く高質の 対人関係一社会性の維持・回復を目指すために一 対 人社会心理学研究, 6, 1-6.

大坊郁夫 (2007). 社会的脈絡に打ける顔コミュニ ケーションへの文化的視点 対人社会心理学研究， 7, $1-10$.

大坊郁夫 (2009). Well-being の心理学を目指す一社 会的スキルの向上と幸福の追究— 対人社会心理学研 究, 9, 25-31.

deTurck, M. A., \& Miller, G. R. (1985). Deception and arousal : Isolating the behavioral correlates of deception. Human Communication Research, 12, 181-201.

Duck, S., Rutt, D. J., Hurst, M. H., \& Strejc, H. (1991). Some evident truths about conversations in everyday relationships : All communication are not created equal. Human Communication Research, 18, 228-267.

遠藤利彦 (2000)。表情を解体する一構成要素的アプ ローチから見る表情の本性一 心理学評論, 43 , 177-198.

遠藤利彦 (2008)。感応する心一視線と表情が発する もの一電子情報通信学会技術研究報告, HCS2008-32 (2008-8), 13-18.

藤本 学・大坊郁夫 (2007a). 小集団による会話の展 開に及ぼす会話者の発話行動傾向の影響 実験社会心 理学研究, 47, 51-60.

藤本 学・大坊郁夫 (2007b). 小集団コミュニケー ションにおける話者の叙述パターン 社会心理学研 究, 23, 23-32.

深田博己 (1998). インターパーソナルコミュニケー ション一対人コミュニケーションの心理学— 北大路 
書房

古谷嘉一郎・坂田桐子 (2006)。対面，携帯電話，携带 メールでのコミュニケーションが友人との関係維持に 及ぼす効果一コミュニケーションのメディアと内容の 適合性に注目して一 社会心理学研究, 22, 72-84.

Giles, H. (1971). Patterns of evaluation to R. P., South Welsh and Somerset accented speech. British Journal of Social and Clinical Psychology, 10, 280-281.

Giles, H., Coupland, N., \& Coupland, J. (1991). Accommodation theory: Communication, context, and consequence. In H. Giles, J. Coupland, \& N. Coupland (Eds.), Contexts of accommodation : Developments in applied sociolinguistics (pp. 1-68). Cambridge : Cambridge University Press.

Gilovich, T., Savitsky, K., \& Medvec, V. H. (1998). The illusion of transparency : Biased assessments of others' ability to read one's emotional state. Journal of Personality and Social Psychology, 75, 332-346.

Goldsmith, D. J., \& Baxter, L. A. (1996). Constituting relationships in talk : A taxonomy of speech events in social and personal relationships. Human Communication Research, 23, 87-114.

Grice, H. P. (1975). Logic and conversation. In P. Cole \& J. L. Morgan (Eds.), Syntax and semantics, Vol.3 : Speech acts (pp. 41-58). New York : Academic Press.

畑中美穂 (2003)。会話場面における発言の抑制が精 神的健康に及ぼす影響 心理学研究, 74, 95-103.

畑中美穂 (2006)。発言抑制行動に至る意思決定過程 一発言抑制行動決定時の意識内容に基づく検討一 社 会心理学研究, 21, 187-200.

葉山大地・櫻井茂男 (2008a)。友人に対する先談関係 の認知が談行動へ及ぼす影響 心理学研究， 79, 18-26.

葉山大地・櫻井茂男 (2008b)。過激な冗談の親和的意 図が伝わるという期待の形成プロセスの検討 教育心 理学研究, 56, 523-533.

石田容士・阿部純一 (2010)。 アイロニーによる非難の 対象は反復的言及によって同定されるか心理学研 究, 80, 485-493.

磯 友輝子・木村昌紀・桜木亜季子・大坊郁夫 (2003). 発話中のうなずきが印象形成に及济す影響— 3 者間会 話場面における非言語的行動の果たす役割— 電子情 報通信学会技術研究報告, HCS2003-25（2003-11)，
$31-36$.

磯 友輝子・木村昌紀・桜木亜季子・大坊郁夫 (2004). 視線行動が印象形成に及ぼす影響一 -3 者間会話場面に おける非言語的行動の果たす役割一 対人社会心理学 研究, 4, 83-91.

上出寬子・大坊郁夫 $(2007)$. 3 次元計測法による顔面 表情に伴う顔形態特徵の測定(2)一日本人大学生の社会 的スキルと顔面表情との関係一 電子情報通信学会技 術研究報告, HCS2007-22 (2007-5), 113-118.

木村昌紀・大坊郁夫・余語真夫 (2010)。社会的スキル としての対人コミュニケーション認知メカニズムの検 討 社会心理学研究, 26, 13-24.

木村昌紀・磯 友輝子・大坊郁夫 (2004)。関係継続の 予期が対人コミュニケーションに及ぼす影響 電子情 報通信学会技術研究報告, HCS2004-10（2004-07）， 1-6.

木村昌紀・磯 友輝子・桜木亜季子・大坊郁夫 (2005). 3 者間会話場面に視覚メディアが果たす役割一笑顔と うなずきの表出，及びそれらの行動マッチングに注目 して一 対人社会心理学研究, 5, 39-47.

木村昌紀・余語真夫・大坊郁夫 (2005). 感情エピソー ドの会話場面における表出性ハロー効果の検討 感情 心理学研究, 12, 12-23.

Knapp, M. L., Hart, R. P., \& Dennis, H. S. (1974). An exploration of deception as a communication construct. Human Communication Research, 1, 15-29.

工藤 カ・ディビット・マツモト (1996). 日本人の感 情世界一ミステリアスな文化の謎を解く 誠信書房

Leary, M. R. (1983). Understanding social anxiety : Social, personality, and clinical perspectives. Beverly Hills, California : Sage Publications. (リアリィ, M. R. 生和秀敏（監訳）（1990）。対人不安 北大路書 房)

町 一誠・樋口匡貴・深田博己（2006）。話し手の方言 使用と印象一コードスイッチの適切さと聞き手の出身 地による影響— 社会心理学研究, 21, 173-186.

Matsumoto, D., \& Ekman, P. (1989). AmericanJapanese cultural differences in intensity ratings of facial expressions of emotion. Motivation and Emotion, 13, 143-157.

McCornack, S. A. (1992). Information manipulation theory. Communication Monographs, 59, 1-16.

守㠃誠一 (2010). 帰納的研究は, 人のコミュニケー ションを明らかにしてくれるのか一非言語研究への演 繹的アプローチの必要性一 対人社会心理学研究, 10, 
$72-74$.

村井潤一郎 （1998）。情報操作理論に基づく発言内容 の欺瞞性の分析 心理学研究, 69, 401-407.

村井潤一郎 (2004). 発言内容の欺瞞性認知一公準の 複数違反で欺瞞性は高まるか? 一 パーソナリティ研 究, 12, 116-117.

村井潤一郎 (2005)。強調語が発言内容の欺瞞性認知 に及ぼす影響 パーソナリティ研究, 14, 92-100.

中村 真 (1991). 情動コミュニケーションにおける 表示・解読規則一概念的検討と日米比較調査一 大阪 大学人間科学部紀要, $17,115-145$.

中村 真 (1993). 情動判断の日米比較 大阪大学人 間科学部紀要, 19, 41-57.

中村 真 (2000). 表情と感情のコミュニケーション 一表示規則と感情表出のモデル— 心理学評論, 43 , 307-317.

落合萌子・松井 豊 (2009). 他者表情が変化する場面 における高対人不安者の表情認知 対人社会心理学研 究, 9, 45-53.

小川一美 (2003a). 二者間発話量の均衡が会話者が抱

く相手と会話に対する印象に及ぼす効果 電子情報通 信学会技術研究報告, HCS2003-26 (2003-11), 37-42. 小川一美 (2003b). 二者間発話量の均衡が観察者が抱

く会話者と会話に対する印象に及ぼす効果 実験社会 心理学研究, 43, 63-74.

小川一美 (2006). 手がかり情報の相違が二者間会話 に対する印象に及ぼす影響 社会言語科学, 9, 27-36.

小川一美 (2008). 会話セッションの進展に伴う発話 の変化-Verbal Response Modesの観点からー 社 会心理学研究, 23, 269-280.

小川一美 (2010a). 対人場面のコミュニケーション 相川 充・高井次郎 (編著) コミュニケーションと対 人関係一展望 現代の社会心理学 2-（pp. 2-19） 誠信書房

小川一美 (2010b). 大学生にとってのコミュニケー ション力とは電子情報通信学会技術研究報告, HCS2009-68 (2010-03), 17-18.

O'Hair, H. D., Cody, M. J., \& McLaughlin, M. L. (1981). Prepared lies, spontaneous lies, machiavellianism, and nonverbal communication. Human Communication Research, 7, 325-339.

岡本真一郎 (1985). 言語的スタイルが説得に及ぼす 効果 実験社会心理学研究, 25, 65-76.

岡本真一郎 (2001). 名古屋方言の使用が話し手の印 象に及ぼす影響 社会言語科学, 3, 4-16.

岡本真一郎 (2004). アイロニーの実験的研究の展望
一理論修正の試みを含めて一心理学評論, 47, $395-420$.

岡本真一郎 (2010). ことばの社会心理学 第 4 版 ナカニシヤ出版

Patterson, M. L. (1983). Nonverbal behavior : A functional perspective. New York : Springer-Verlag. （パターソン, M. L. 工藤 力（監訳） (1995). 非言語コミュニケーションの基礎理論 誠信書房)

佐々木美加 (2005). 協調か対決かーコンピューター コミュニケーションの社会心理学一 ナカニシヤ出版 佐々木美加 (2006). 会話中の不一致メッセージが受 信者の帰属, 感情, 行動に与える影響 社会言語科学, 9, 37-47.

Schlenker, B. R., \& Leary, M. R. (1982). Social anxiety and self-presentation : A conceptualization and model. Psychological Bulletin, 92, 641-669.

Stiles, W. B. (1992). Describing talk : A taxonomy of verbal response modes. New bury Park, CA : Sage Publications.

太幡直也（2006）。被透視感の強さを規定する要因 一自己への注意と他者の視点取得についての検討一 社会心理学研究, 22, 19-32.

太幡直也 (2008). 認知的負荷が懸念的被透視感に よって生起する反応に与える影響 心理学研究， 79 , 333-341.

太幡直也 (2010)。内面の被知覚の意識に関する研究 の展望一概念の整理を中心に一 パーソナリティ研 究, 18, 210-219.

太幡直也・吉田富二雄 （2008）。懸念的被透視感が生じ る状況の特徴 筑波大学心理学研究, 36, 11-17.

多川則子・小川一美・斎藤和志 （2006）。 日常的コミュ ニケーションにおける話題の収集を目指してーテーマ の重要性判断に基づく検討一 対人社会心理学研究, 6, 71-79.

多川則子・吉田俊和 (2006). 日常的コミュニケーショ ンが恋愛関係に及ぼす影響 社会心理学研究， 22 , 126-138.

武田美亜・沼崎 誠 (2007)。相手との親密さが内的経 験の積極的伝達場面における 2 種類の透明性の錯覚に 及ぼす効果 社会心理学研究, $23,57-70$.

武田美亜・沼崎 誠 (2009). 共通基盤知覚がさまざま な内的経験の透明性の錯覚に及ぼす影響 対人社会心 理学研究, 9, 55-62.

竹中一平 (2005). 対人コミュニケーションの観点か

ら見たうわさの伝達 社会心理学研究, 21, 102-115. 竹中一平 (2007). 大学生の日常会話におけるうわさ 
の類型化 心理学研究, 78, 433-440.

谷村圭介・渡辺弥生 (2008). 大学生におけるソーシャ ルスキルの自己認知と初対面場面での対人行動との関 係 教育心理学研究, 56, 364-375.

塚脇涼太・越 良子・樋口匡貴・深田博己 (2009). な ぜ人はユーモアを感じさせる言動をとるのか？ーユー モア表出動機の検討一 心理学研究, 80, 397-404.

内田照久 (2002)。音声の発話速度が話者の性格印象 に与える影響 心理学研究, 73, 131-139.

内田照久 (2005a)。音声の発話速度と休止時間が話者 の性格印象と自然なわかりやすさに与える影響 教育 心理学研究, 53, 1-13.
内田照久 (2005b). 音声中の抑揚の大きさと変化パ ターンが話者の性格印象に与える影響 心理学研究, 76, 382-390.

内田照久・中畧菜穂子 (2004). 声の高さと発話速度が 話者の性格印象に与える影響 心理学研究, 75 , 397-406.

横山ひとみ (2010)。 マルチ・チャネル・アプローチに よる説得・依頼 対人社会心理学研究, 10, 56-58.

Yokoyama, H., \& Daibo, I. (2008). The role of speech rate and gaze in persuasion. The 29th International Congress of Psychology, 525. 